Kajian Jurnalisme

ISSN 2549-0559 (cetak) ISSN 2549-1946 (online)

Volume 01 Nomor 02 Tahun 2018

\title{
Makna Jurnalistik Bagi Jurnalis Media Anak
}

\author{
Cendikia Panggih Mulyani’ Nuryah Asri Sjafirah, Pandan Yudhapramesti \\ Program Studi Ilmu Jurnalistik, Fakultas Ilmu KomunikasiUniversitas Padjadjaran \\ cendikiapm@gmail.com
}

\begin{abstract}
Bobo magazine was the most popular children magazine in Indonesia. It had been published since 1973, presenting stories and educative articles. The research aimed to determine journalist-meaning through journalists' motive on choosing a career in journalism field, their journalistic experiences, and their self concept. This research used qualitative research method, with phenomenological approach to four journalists of Bobo magazine. The result showed subjects were affected by because-motive on choosing their career in journalism field. Their experiences included challenges to meet the needs of reader, to meet the wants of company by following writing criteria, and to meet the wants of their sources by citating their words without losing its meaning. The subject saw theirselves as somebody who helps guiding children and giving useful knowledge. The research concluded that the meaning of journalistic for Bobo magazine journalists is an activity in which could benefitted the reader and helped spreading positive knowledge.
\end{abstract}

Keywords: children media, children media journalist, Bobo magazine phenomenology

\begin{abstract}
Abstrak
Majalah Bobo adalah majalah anak paling populer di Indonesia. Majalah in telah terbit sejak 1973 dan menyajikan cerita serta artikel pengetahuan. Tujuan penelitian adalah mengetahui makna jurnalistik bagi jurnalis majalah Bobo melalui motif jurnalis majalah Bobo dalam memilih pekerjaan di bidang jurnalistik, pengalaman para jurnalis majalah Bobo dalam melakoni pekerjaannya, dan konsep diri jurnalis majalah Bobo. Penelitian menggunakan metode penelitian kualitatif, dengan pendekatan fenomenologi terhadap empat jurnalis majalah Bobo. Hasil penelitian menunjukkan para informan dipengaruhi oleh motif sebab (because motive) dalam memilih pekerjaan di bidang jurnalistik. Pengalaman mereka berkisar pada tantangan untuk memenuhi kebutuhan pembaca anakanak, memenuhi keinginan perusahaan dengan mengikuti aturan penulisan yang sesuai kriteria, dan memenuhi keinginan narasumber dengan menuliskan kembali perkataan narasumber tanpa menggeser maknanya. Konsep diri jurnalis majalah Bobo secara umum adalah sebagai sosok yang membantu membimbing anak-anak dan memberikan ilmu yang bermanfaat. Penelitian ini menyimpulkan makna jurnalistik bagi jurnalis majalah Bobo adalah kegiatan yang dapat memberikan manfaat dan ilmu yang positif bagi pembacanya.
\end{abstract}

Kata kunci: media anak, jurnalis media anak, majalah Bobo, fenomenologi 
148 | Kajian Jurnalisme

ISSN 2549-0559 (cetak) ISSN 2549-1946 (online)

Volume 01 Nomor 02 Tahun 2018

\section{Pendahuluan}

Berita atau informasi tidak dapat dipisahkan dari kehidupan manusia. Sebagai makhluk sosial, manusia selalu membutuhkan berita atau informasi baru untuk memperluas wawasannya dan untuk mendewasakan alam berpikirnya. Manusia tidak dapat menghindar dari kehidupan bermasyarakat. Manusia tidak mungkin merasa sempurna hidupnya tanpa bermasyarakat. Dalam kehidupan ber-masyarakat, manusia tidak bisa hidup secara sempurna tanpa berkomunikasi, artinya manusia tidak akan bisa dipisahkan dengan permasalahan penerimaan dan penyampaian berita. (Ermanto, 2005:78)

Kebutuhan akan informasi ini tidak hanya ingin dipenuhi oleh orang dewasa, tetapi juga anak-anak. Informasi yang mereka butuhkan terkait dengan pendidikan, seperti kabar terbaru dari dunia ilmu pengetahuan dan teknologi; dan hiburan, seperti informasi terkini dari film kesukaannya. Kebutuhan ini dapat mereka penuhi dari berbagai jenis media massa seperti televisi, artikel internet, dan majalah.

Di Indonesia hingga saat ini terdapat beberapa majalah anak yang beredar di pasaran, baik untuk anak usia dini (TK/PAUD) maupun untuk anak usia 6-12 tahun atau usia sekolah dasar (SD). Sebut saja Bobo, Bobo Junior, Mombi, Mombi SD, XY Kids, National Geographic Kids, Girls, Princess, Kreatif, dan lainnya. Dari seluruh majalah yang masih terbit hingga saat ini, majalah Bobo merupakan yang tertua, terbit sejak 14 April 1973. Mengusung jargon "Teman Bermain dan Belajar", majalah ini tidak hanya memberikan cerita dalam bentuk cergam (cerita bergambar), cerpen, atau dongeng, tetapi juga pengetahuan dan beragam artikel yang dekat dengan dunia anak-anak. Majalah ini terbit satu minggu sekali setiap hari Kamis.

Menurut Amna (2017) keberadaan majalah Bobo bermula dari halaman anak-anak di Harian Kompas. Pendiri Kompas, PK Ojong dan Jakob Oetama pun mengembangkan halaman ini menjadi majalah anak-anak. Bekerja sama dengan Majalah Bobo Belanda, pengasuh halaman anak-anak Kompas pun membuat Majalah Bobo Indonesia. Pada mulanya majalah Bobo terdiri dari 16 halaman kertas koran. Majalah Bobo adalah majalah anak-anak pertama yang berwarna di Indonesia. Sebagian isinya berasal dari bahan-bahan di Majalah Bobo Belanda yang diterjemahkan ke dalam bahasa Indonesia. Sebagiannya lagi meneruskan rubrik dari halaman anak-anak Kompas. Eksistensi majalah Bobo ini melekatkan citra dirinya sebagai majalah anak-anak paling populer di Indonesia. Dibandingkan dengan majalah anak lainnya, informasi yang disampaikan oleh majalah Bobo lebih beragam dan umum, mulai dari cerita hingga pengetahuan. Majalah XY Kids misalnya, lebih memfokuskan pada informasi mengenai film, permainan (games), olahraga, teknologi, dan musik.

Selain rubrik cerpen (cerita pendek), dongeng, dan cergam (cerita bergambar), rubrik lain yang rutin muncul di majalah bermaskot kelinci tersebut adalah rubrik "Profil" yang menyajikan profil sosok terkenal atau menginspirasi; "Potret Negeriku" yang menyajikan potret sosial-budaya dari seluruh Indonesia; "Flora" dan "Fauna" yang hadir secara bergiliran setiap minggunya dengan ulasan mengenai hewan atau tumbuhan unik; "Film" dan "Buku Pilihanku" yang mengulas film dan buku terbaru; "Reportasia" dan "Info Bobo" yang menyajikan liputan suatu acara (event); "Keliling Dunia" yang menyajikan artikel tempat- 
tempat unik dari seluruh dunia. Terdapat pula rubrik "Boleh Tahu" yang menyajikan informasi-informasi singkat dalam bentuk karikatur. Muatan artikel yang ada di majalah Bobo menyesuaikan dengan ke-butuhan informasi anak-anak usia Sekolah Dasar, sesuai dengan segementasi majalahnya.

Tidak semua artikel yang disajikan memiliki nilai aktualitas, tetapi peneliti menilai artikel-artikel tersebut bermanfaat untuk pembacanya. Nilai aktualitas majalah Bobo biasanya terdapat pada saat-saat tertentu, seperti hari raya, hari kemerdekaan, atau membahas hal-hal yang sedang tren di kalangan anak-anak seperti tren gadget atau acara televisi yang sedang digandrungi anak-anak.

Dalam beberapa kondisi, nilai aktualitas majalah Bobo kemudian tidak hanya terbatas pada topik hangat di kalangan anak-anak. Majalah Bobo juga sering mengangkat isu nasional dengan sudut pandang yang berbeda. Tidak semua isu nasional diangkat oleh majalah Bobo. Aan Kurniawati Madrus, mantan Redaktur Majalah Bobo mengatakan, pemilihan tema yang sesuai dengan isu nasional menyesuaikan dengan hal-hal yang memang perlu diketahui oleh anak-anak.

Contohnya pada kasus kabut asap yang melanda sebagian wilayah Sumatera dan Kalimantan pada 2015 lalu. Koran harian dan majalah yang diperuntukkan bagi orang dewasa secara berkelanjutan memberitakan peristiwa tersebut, mulai dari hutan yang terbakar, apa penyebabnya, seperti apa dampaknya, hingga pihak-pihak yang diduga bertanggung jawab atas insiden tersebut. Namun, majalah Bobo merangkum seluruh peristiwa itu dalam satu artikel yang mem-bahas bagaimana kabut asap terjadi, bagai-mana menghadapi kabut asap, dan dampaknya terhadap kehidupan anak-anak.

Penyajian informasi di media massa untuk anak-anak seperti majalah Bobo tentunya berbeda dengan media massa untuk orang dewasa, baik dari gaya bahasa maupun desain dan tata letak (layout). Media massa dengan segmentasi dewasa, terutama dalam berita langsung di surat kabar, biasanya menyajikan informasi secara kaku. Artinya, dalam penulisan naskah tidak terasa adanya kedekatan antara penulis dan pembaca. Sementara di majalah Bobo, bahasa yang digunakan terasa sangat akrab, seperti seorang sahabat yang bercerita kepada kawannya. Bacaan bagi anak-anak menggunakan paragraf dan kalimat-kalimat yang pendekpendek, serta kata-kata yang sesuai dengan perkembangan jiwa mereka (Sumadiria, 2006: 82). Dalam kalimat jurnalistiknya, majalah Bobo sering menggunakan kata tutur atau bahasa percakapan. Misalnya, menggunakan kata enggak, atau penegasan dengan kata lo.

Dalam penulisan yang berkaitan dengan nama orang pun kerap kali menggunakan sapaan seperti "pak", "bu", atau "kak". Hal ini seolah menyesuaikan dengan sopan-santun orang Indonesia untuk meng-gunakan sapaan tersebut kepada orang yang lebih tua.

Bahasa jurnalistik tunduk kepada kaidah bahasa baku dan sesuai dengan EYD (Ejaan yang Disempurnakan). Dalam buku Pedoman Umum Ejaan Bahasa Indonesia yang Disempurnakan dan Pedoman Umum Pembentukan Istilah (Pustaka Setia, 2012) disebutkan salah satu ciri bahasa baku adalah bukan merupakan bahasa percakapan. Persatuan Wartawan Indonesia (PWI) (dalam Sumadiria, 20016: 193) mengeluarkan sepuluh pedoman pemakaian bahasa dalam pers. Butir pertama dalam pedoman itu menyebutkan, 
$150 \mid$ Kajian Jurnalisme

ISSN 2549-0559 (cetak) ISSN 2549-1946 (online)

Volume 01 Nomor 02 Tahun 2018

"Wartawan hendaknya secara konsekuen melaksanakan Pedoman Ejaan Bahasa Indonesia yang disempurnakan. Hal ini juga harus diperhatikan oleh para korektor karena kesalahan paling menonjol dalam surat kabar sekarang ini ialah kesalahan ejaan."

Seperti halnya media massa dengan segmentasi remaja dan dewasa, redaksional majalah Bobo pun diisi oleh orang-orang dewasa. Hal ini peneliti rasa menarik, sebab tentu sulit bagi orang dewasa untuk menempatkan dirinya sejajar dengan anak usia sekolah dasar karena orang dewasa cenderung memiliki pikiran yang lebih kompleks. Tentunya tidak semua orang ingin menjadi wartawan media massa untuk anak-anak seperti majalah Bobo, baik mereka yang memiliki latar belakang pendidikan jurnalistik maupun bukan. Peneliti tertarik untuk mengetahui apa motif jurnalis majalah anak-anak seperti Bobo untuk bergabung dengan majalah tersebut. Peneliti menilai bahwa para jurnalis majalah Bobo adalah orang yang peduli dengan asupan informasi bagi anak-anak. Apalagi mengingat saat ini anak-anak mudah sekali terpengaruh oleh tayangan televisi atau konten di internet.

Selain itu, profesi jurnalis biasanya dikaitkan dengan kegiatan menguak kebenaran yang berusaha disembunyikan. Yunus (2010: 38) mengatakan profesi wartawan merupakan profesi yang disegani oleh publik. Sebab, wartawan dianggap kritis dan tajam dalam bertanya, mampu mengungkap informasi secara rinci, piawai dalam meliput berita, dan mampu mempengaruhi orang lain melalui tulisannya. Lebih lanjut, Yunus mengatakan,

"Tugas wartawan tidaklah ringan. Disamping penuh dinamika dan tantangan, tugas wartawan pun sering kali memiliki ancaman tersendiri. Pemberitaan yang dianggap tidak objektif pun dapat mengancam keselamatan diri wartawan. Karena itu, wartawan harus dapat melaksanakan tugas pemberitaan yang menjunjung tinggi objektivitas dan profesionalisme, disamping memper-hatikan tanggung jawab yang harus diembannya." (2010: 40)

Sosok yang biasanya dijadikan panutan di kelas-kelas jurnalistik misalnya Veronica Guerin, jurnalis Irlandia yang meninggal ketika sedang melakukan investigasi kasus penyelundupan narkoba, atau Fuad Muhammad Syafruddin alias Udin, wartawan Harian Bernas Yogyakarta yang dibunuh pada tahun 1996 karena tulisan-tulisannya yang mengkritisi kebijakan Orde Baru. Sementara menjadi jurnalis di media anak-anak tidaklah demikian. Jurnalis di media anak tidak perlu menceburkan dirinya ke sarang penyamun atau mengusik kehidupan para pejabat, sebab anak-anak memang tidak membutuhkan informasi seperti itu. Bagi mereka, profesi jurnalis media anak merupakan pekerjaan mulia seperti halnya guru SD yang membekali generasi yang akan datang dengan pesan-pesan yang bermanfaat.

Pengalaman yang dialami jurnalis majalah Bobo dalam menjalani profesinya itu tentu berbeda dengan jurnalis yang bekerja di kompartemen politik, ekonomi, atau olahraga di media segmentasi dewasa seperti koran harian, situs dan majalah berita, atau televisi. Sehingga, peneliti tertarik untuk mengetahui manfaat yang didapat jurnalis majalah Bobo dari pengalamannya itu.

Untuk menggali makna jurnalistik bagi jurnalis majalah Bobo, peneliti juga akan menggali pengetahuan mereka tentang dunia jurnalistik dan dunia anak-anak. Peneliti ingin 
mengetahui bagaimana jurnalis majalah Bobo mengidentifikasi pekerjaan mereka sebagai kegiatan jurnalisme, serta seperti apa pengetahuan mereka mengenai isu yang dekat dengan dunia anak-anak. Peneliti pun tertarik mengetahui bagaimana jurnalis-jurnalis ini memaknai isu yang berhubungan dengan dunia anak dan dekat dengan pekerjaan mereka.

Penelitian ini mengupas tentang fenomena yang dialami oleh jurnalis majalah Bobo, sehingga pendekatan yang digunakan adalah pendekatan fenomenologi. Tujuan utama fenomenologi adalah mempelajari bagaimana fenomena dialami dalam kesadaran, pikiran, dan dalam tindakan, seperti bagaimana fenomena tersebut bernilai atau diterima secara estetis (Kuswarno, 2009: 2).

\section{Metode Penelitian}

Metodologi adalah proses, prinsip, dan prosedur yang akan digunakan untuk mendekati problem dan mencari jawaban. Dengan kata lain, metodologi dipengaruhi atau berdasarkan perspektif teoretis yang digunakan untuk melakukan penelitian, sementara perspektif teoretis itu adalah suatu kerangka penjelasan atau interpretasi yang memungkinkan peneliti memahami data dan menghubungkan data yang rumit dengan peristiwa situasi lain (Mulyana, 2001: 145).

Penelitian ini menggunakan metodologi kualitatif. Metode ini peneliti nilai tepat untuk digunakan karena data yang dihasilkan berupa data deskriptif berisi kata-kata tertulis dan penggambaran hasil observasi dan wawancara. Bogdan dan Taylor (dalam Moleong, 2012: 4) mendefinisikan metodologi kualitatif sebagai prosedur penelitian yang menghasilkan data deskriptif berupa kata-kata tertulis atau lisan dari orang-orang atau perilaku yang dapat diamati. Kirk dan Miller (dalam Moleong, 2012: 4) mendefiniskan bahwa penelitian kualitatif adalah tradisi tertentu dalam ilmu pengetahuan sosial yang secara fundamental bergantung dari pengamatan pada manusia baik dalam kawasannya maupun dalam peristilahannya. Penelitian kualitatif menghendaki pelaksanaan penelitian berdasarkan situasi wajar (natural setting) sehingga kerap juga orang menyebutnya sebagai metode naturalistik. Secara sederhana dapat dinyatakan bahwa penelitian kualitatif adalah meneliti informan—sebagai subjek penelitian—dalam lingkungan hidup kesehariannya (Idrus, 2009: 23).

Idrus dalam bukunya Metode Penelitian Ilmu Sosial: Pendekatan Kualitatif dan Kuantitatif, Edisi Kedua (2009: 27) mengatakan salah satu ciri penelitian kualitatif adalah berorientasi pada kasus unik. Suatu penelitian kualitatif yang baik akan dapat menampilkan kedalaman dan detail suatu fenomena yang tengah diteliti karena fokus penelitian kualitatif memang menyelidiki suatu kasus secara mendalam. Kasus unik dalam hal ini bukan berarti kasus yang aneh, dalam artian tidak seperti pada umumnya. Namun, dalam setiap fenomena yang tengah diteliti, ada kasus-kasus tertentu yang sifatnya khas dan unik untuk situasi itu. Dalam konteks penelitian ini, peneliti menilai keberadaan jurnalis untuk media anak-anak adalah kasus yang unik. Sebab, tidak semua orang mau bekerja menyampaikan informasi bagi segmentasi anak-anak, sehingga seorang jurnalis yang bekerja di media anak adalah hal yang unik dan berbeda dari jurnalis lainnya. 
Pendekatan yang digunakan dalam penelitian ini adalah pendekatan fenomenologi. Konsep fenomenologi bermula dari pandangan Edmund Husserl yang meyakini bahwa sesungguhnya objek ilmu itu tidak terbatas pada hal-hal yang empiris (terindra), tetapi juga mencakup fenomena yang berada di luar itu, seperti persepsi, pemikiran, kemauan, dan keyakinan subjek tentang "sesuatu" di luar dirinya (Idrus, 2009: 58). Dewasa ini fenomenologi dikenal sebagai aliran filsafat sekaligus metode berpikir, yang mempelajari fenomena manusiawi (human phenomena) tanpa mempertanyakan penyebab dari fenomena itu, realitas objektifnya, dan penampakannya. Tujuan utama fenomenologi adalah mempelajari bagaimana fenomena dialami dalam kesadaran, pikiran, dan dalam tindakan, seperti bagaimana fenomena tersebut bernilai atau diterima secara estetis. Fenomenologi mencoba mencari pemahaman bagaimana manusia mengkonstruksi makna dan konsepkonsep penting, dalam kerangka intersubjektivitas (Kuswarno, 2009: 2).

Penelitian fenomenologi seringkali diidentikkan dengan penelitian naturalistik. Peneliti naturalistik memasuki arena penelitian yang diminatinya untuk menafsirkan fenomena yang ditemuinya, tidak memanipulasi atau mengontrolnya, dan berusaha mencampurinya sesedikikt mungkin. Peneliti naturalistik menekankan logics in action, yakni logika individu-individu yang diteliti, alih-alih logika formal. Seperti dalam pandangan kaum interaksionis, individu-individu diasumsi-kan aktif, berencana, bertujuan, dan menafsirkan perilaku diri sendiri dan perilaku orang lain (Mulyana, 2001: 159). Tujuan dari semua paham fenomenolog yang beragam sifatnya pada dasarnya sama, yakni memahami subjek dari sudut pandang subjek sendiri (Bogdan \& Biklen, dalam Ahmadi, 2014: 48).

Penelitian ini dilakukan dengan melakukan wawancara dan observasi terhadap empat jurnalis yang hingga saat ini masih aktif menulis di majalah Bobo. Informan dalam penelitian ini yaitu Theresia Widyantini (Yanti) yang menjabat sebagai redaktur, dan tiga reporter yaitu Sylvana Anastasia Hamaring (Ana), Iveta Rahmalia (Veta), dan Marisa Febrilian (Marisa).

\section{Hasil Dan Pembahasan}

Penelitian ini telah dilakukan pada 19 September 2017 melalui observasi dan wawancara dengan subjek penelitian di kantor redaksi majalah Bobo. Wawancara dilakukan sore hari ketika informan sedang beristirahat sejenak dari pekerjaannya, sehingga wawancara dapat dilakukan dalam suasana santai.

Hasil wawancara dan observasi ini akan dituangkan dalam tiga bagian, yaitu motif informan bergabung dengan majalah Bobo, pengalaman jurnalis majalah Bobo, dan konsep diri jurnalis majalah Bobo.

\section{Motif Jurnalis Bergabung dengan Majalah Bobo}

Menurut Kamus Besar Bahasa Indonesia, motif adalah alasan (sebab) seseorang melakukan sesuatu. Motif merupakan dorongan dalam diri manusia yang timbul karena adanya kebutuhan-kebutuhan yang ingin dipenuhi oleh manusia tersebut. Dalam penelitian ini, motif yang digali adalah motif sosiogenis, yaitu motif yang berperan dalam membentuk perilaku sosial (Rakhmat, 2011). Berdasarkan hasil wawancara, motif para informan dibagi 
berdasarkan sesuai dengan latar belakang pendidikan, menyukai dunia anak-anak, dan membutuhkan pekerjaan.

Seluruh informan dalam penelitian ini sebelumnya tidak memiliki pengalaman jurnalistik secara profesional. Mereka memiliki latar belakang pendidikan berbeda-beda, mulai dari bidang yang dekat dengan dunia media dan jurnalistik, hingga yang tidak berhubungan sama sekali. Namun, rupanya para informan memiliki motif yang nyaris sama untuk memutuskan bekerja di majalah Bobo, yaitu kesukaan mereka pada anak-anak dan dunia tulis-menulis. Selain itu, para informan merasa bekerja di majalah Bobo membuat mereka dapat membantu mendidik anak-anak dengan cara yang menyenangkan dan berbeda dengan sistem pengajaran di sekolah.

Dari keempat informan, hanya Veta dan Marisa yang memiliki latar belakang pendidikan yang sesuai dengan profesi mereka saat ini, yaitu Ilmu Komunikasi dengan peminatan bidang Jurnalistik.

Veta adalah Sarjana Ilmu Komunikasi dari Universitas Multimedia Nasional. Sebelum memulai kariernya di majalah Bobo, Veta tidak memiliki pengalaman profesional dari bekerja di media atau perusahaan lain. Ia hanya pernah magang semasa kuliah di bagian digital media yang masih bernaung di bawah Kompas Gramedia. Saat menjalani magang selama tiga bulan itu, Veta diminta untuk menulis konten digital untuk media segmentasi dewasa, misalnya saat itu ia diminta untuk meliput acara Jakarta Fashion Week. Selain pengalaman magang itu, Veta sama sekali tidak pernah belajar bagaimana menulis untuk anak-anak. Pengetahuan itu baru didapatnya sembari belajar menjadi jurnalis majalah Bobo.

Marisa merupakan teman seangkatan Veta di jurusan Ilmu Komunikasi Universitas Multimedia Nasional. Ia mengawali karier di Majalah Bobo sejak masih menjalani kewajiban magang dari kampus di tahun 2013 selama tiga bulan. Setelah itu, di sela-sela pengerjaan skripsi ia melanjutkan menjadi pekerja lepas untuk Bobo hingga akhirnya ia lulus kuliah dan resmi bergabung dengan anggota redaksi pada tahun 2014. Sementara Ana merupakan lulusan Teknik Sipil dari Universitas Trisakti dan sebelum nya sempat bekerja di sebuah perusahaan retail; dan Yanti adalah Sarjana Sastra Jerman dari Universitas Padjadjaran. Mereka berdua tidak memiliki latar belakang pendidikan jurnalistik ataupun pengalaman bekerja di media sebelumnya.

Ketika masih bekerja di toko retail dan membuka usaha, Ana sudah menulis ratusan cerita anak sebagai bagian dari hobinya sejak kecil. Cerita-cerita itu ia kirimkan ke berbagai media, seperti koran Minggu dan majalah anak-anak, termasuk majalah Bobo. Beberapa lainnya ia unggah di blog pribadinya, anatoemon.com. Berangkat dari kesukaannya menulis cerita anak inilah yang membuat Ana akhirnya memutuskan untuk berhenti dari pekerjaan sebelumnya dan memutuskan untuk bergabung dengan redaksi majalah Bobo. Menurut Ana, pengalamannya selama menulis cerita anak berpengaruh terhadap pekerjaannya sebagai jurnalis majalah Bobo saat ini. Berkat hobinya menulis cerita anak itu, Ana terbiasa berpikir dari sudut pandang anak-anak dan menggunakan gaya bahasa anak-anak.

Veta juga mengakui ia sudah menyukai dunia tulis-menulis sejak kecil, tetapi ia sebelumnya tidak pernah terpikir untuk menjadikan kesukaannya itu sebagai profesi. Waktu 
154 | Kajian Jurnalisme

ISSN 2549-0559 (cetak) ISSN 2549-1946 (online)

Volume 01 Nomor 02 Tahun 2018

kecil, Veta mengaku cita-citanya adalah menjadi astronot. Begitu kuliah, Veta justru memutuskan untuk masuk ke jurusan Ilmu Komunikasi dan memilih bidang jurnalistik yang semakin meyakinkan dirinya untuk memulai karier di bidang jurnalistik. Ia memilih untuk bekerja di majalah Bobo karena ia sendiri tertarik ingin mengetahui seperti apa itu jurnalistik untuk anak-anak. Selain itu ia juga mengaku tidak begitu memahami bidang hukum atau politik yang biasanya menjadi ranah jurnalistik media segmentasi dewasa.

Hal yang sama juga dikemukakan oleh Marisa. Awalnya Marisa ingin menjalani magang di media yang mengulas masakan dan tata boga, tetapi ternyata latar belakang pendidikan yang dibutuhkan adalah jurusan masakan atau tata boga, bukan sekadar bisa menulis. Akhirnya, Marisa pun memutuskan untuk magang di majalah Bobo yang sejak awal juga sudah menjadi pilihan keduanya karena ia juga menyukai dunia anak-anak. Selesai magang, Marisa masih menjadi pekerja lepas (freelance) untuk majalah Bobo sambil mengerjakan skripsi. Begitu lulus, ia sempat berusaha melamar di perusahaan dan instansi lain. Misalnya, ia bercerita pernah mencoba melamar ke bagian hubungan masyarakat di sebuah sekolah, tetapi tidak diterima. Akhirnya Marisa pun bekerja purnawaktu di redaksi majalah Bobo sejak tahun 2014.

Berbeda dengan koleganya yang lain, Yanti sebelumnya sama sekali tidak pernah terpikir untuk bekerja di media, apalagi media anak. Ketika ia lulus kuliah, saat itu Indonesia sedang mengalami krisis moneter. Awalnya Yanti berusaha melamar pekerjaan ke berbagai perusahaan Jerman, Kedutaan Jerman, dan institusi lain yang berhubungan dengan latar belakang pendidikannya, tetapi ia tidak kunjung diterima bekerja. Setelah berkali-kali gagal mendapatkan pekerjaan, Yanti akhirnya diterima bekerja di majalah Bobo pada tahun 2000. Saat itu, majalah Bobo membutuhkan calon reporter dengan latar belakang berbagai bahasa asing, salah satunya bahasa Jerman.

Schutz (dalam Kuswarno, 2009: 110) menjelaskan bahwa melihat ke depan pada masa yang akan datang (looking-forward into the future) merupakan hal yang esensial bagi konsep tindakan atau action (handeln). Tindakan adalah perilaku yang diarahkan untuk mewujudkan tujuan pada masa datang yang telah ditetapkan (determinate). Kalimat tersebut sebenarnya mengandung makna juga bahwa seseorang memiliki masa lalu (pastness). Dengan demikian tujuan tindakan memiliki elemen ke masa depan (futurity) dan elemen ke masa lalu (pastness).

Kemudian Schutz (dalam Kuswarno, 2009:111) mengatakan untuk menggambarkan tindakan seseorang, perlu diberi fase. Dua fase yang diusulkan Schutz diberi nama tindakan in-order-to motive (Um-zu-motiv), yang merujuk pada masa yang akan datang; dan tindakan because-motive (Weil-Motiv) yang me-rujuk pada masa lalu. Dalam konteks penelitian ini, para jurnalis majalah Bobo bisa jadi memiliki satu dari dua motif yang disebutkan oleh Schutz ketika memilih untuk bekerja di majalah Bobo.

Ana yang sebelumnya telah bekerja di bidang penjualan/retail akhirnya memilih untuk bekerja di majalah Bobo karena hobinya menulis cerita anak sejak dulu dan alasan lainnya. "Dulu sempat punya usaha sendiri. Begitu masuk sini kan agak keteteran lah ya, susah. Akhirnya ya udah aku lepasin," jelasnya. Tindakan Ana untuk meninggalkan pekerjaan 
lamanya dan kemudian bergabung dengan redaksi majalah Bobo terjadi karena adanya because-motive yang merujuk pada masa lalu Ana yang menyukai dunia tulis-menulis. Selain itu, adanya in-order-to-motive yang merujuk pada pengalaman Ana yang tidak mampu mengurus dua pekerjaan sekaligus juga memengaruhi tindakan Ana tersebut.

Sama halnya dengan Veta yang juga suka menulis sejak kecil dan kemudian memilih jurnalistik sebagai pendidikannya. Rasa penasaran Veta terhadap dunia jurnalistik untuk anak-anak, ditambah dirinya yang juga tidak menyukai bidang hukum atau politik yang biasanya menjadi ranah media segementasi dewasa membuatnya mantap memilih pekerjaan sebagai jurnalis majalah Bobo. Dalam hal ini, tindakan Veta untuk memilih bekerja di majalah Bobo dipengaruhi oleh in-order-motive yang merujuk pada Veta yang menghindari bidang hukum atau politik, dan because-motive yang merujuk pada kesukaan Veta menulis sejak kecil.

Pengaruh masa lalu atau because-motive untuk memilih pekerjaan di majalah Bobo juga dialami oleh Marisa yang bahkan sudah berkecimpung di dunia jurnalistik anak-anak sejak masih menjalani kewajiban magang semasa kuliah. Kecintaannya terhadap anak-anak pun menjadi motivasi Marisa untuk terus bekerja di majalah Bobo. Selain itu, misi majalah Bobo untuk menjadi teman bermain dan belajar bagi generasi penerus bangsa sesuai dengan misi pribadi Marisa.

“... kalau aku sih ngerasanya gitu tiap kali ketemu anak-anak tuh bawaannya happy padahal tadinya malas-malasan atau capek, gitu. Begitu ketemu mereka tuh langsung yang kayak senang, gitu. Itu lagi makanya motivasi kenapa aku terus di Bobo, selain emang suka sama anak-anak gitu karena emang misi dari Bobo sendiri tuh cocok gitu sama aku walaupun aku nulis emang buat anak-anak, tapi anak-anak itu penerus generasi bangsa..."

Berbeda dengan Yanti yang sebelumnya bahkan tidak pernah terpikir untuk bekerja di media, apalagi media anak-anak. Yanti akhirnya memilih untuk bekerja di Bobo setelah berkali-kali gagal melamar ke berbagai perusahaan Jerman. Motif Yanti ini dapat dikatakan sebagai in-order-to motive yang berorientasi pada masa yang akan datang, karena Yanti membutuhkan pekerjaan pada 18 tahun yang lalu ketika ia memulai kariernya. Namun, pada akhirnya Yanti sangat menikmati pekerjaannya saat ini, bahkan ia tidak berpikir untuk pindah ke tempat lain. Motif kedua (because-motive) ini muncul setelah Yanti merasakan bahwa bekerja di media anak-anak adalah pekerjaan yang menyenangkan dan sesuai dengan dirinya yang menyukai anak-anak. Lingkungan kerja yang nyaman pun membuat Yanti urung mengganti profesinya.

"Kenapa betah? Ya dulu apa sih... emang saya suka anak-anak ya, jadi saya senang aja gitu dengan bidang yang dikerjakan, jadi kerjaan yang dikerjain itu enak aja gitu, cocok aja. Jadi belum ada niatan pindah ke mana-mana."

Selain fase yang diberikan oleh Schutz tersebut, motif sosiogenis yang mempengaruhi tindakan jurnalis majalah Bobo dalam memilih pekerjaannya adalah motif kompetensi dan kebutuhan pemenuhan diri seperti yang dijelaskan oleh Rakhmat (2009:37-38). Terkait dengan motif kompetensi, Rakhmat mengatakan setiap orang ingin membuktikan bahwa ia 
156 | Kajian Jurnalisme

ISSN 2549-0559 (cetak) ISSN 2549-1946 (online)

Volume 01 Nomor 02 Tahun 2018

mampu mengatasi persoalan kehidupan apa pun. Perasaan mampu amat bergantung pada perkembangan intelektual, sosial, dan emosional.

Motif kompetensi erat hubungannya dengan kebutuhan akan rasa aman. Orang seperti Veta dan Marisa yang memilih pekerjaan yang sesuai dengan latar belakang pendidikannya bisa jadi dipengaruhi oleh motif kompetensi ini. Mereka ingin membuktikan bahwa ilmu yang mereka dapatkan selama perkuliahan dapat diaplikasikan di dunia kerja. Hal ini juga dibuktikan dengan perjalanan mereka ketika mencari pekerjaan yang masih berhubungan dengan latar belakang pendidikannya sebelum berakhir di majalah Bobo.

Motif lain yang berpengaruh adalah kebutuhan pemenuhan diri. Dalam Teori Hierarki Kebutuhan yang digagas oleh Abraham Maslow, kebutuhan pemenuhan diri berada di puncak piramida. Artinya, dorongan untuk memenuhi kebutuhan ini hanya akan muncul ketika kebutuhan lain telah terpenuhi. Maslow menggambarkan aktualisasi atau pemenuhan diri sebagai sesuatu yang harus dipenuhi seseorang karena ia terlahir untuk itu. Misalnya musisi harus bermusik, atau penulis harus menulis. Coleman (dalam Rakhmat, 2009:38) mengatakan,

"Kita bukan saja ingin mem-pertahankan kehidupan, kita juga ingin meningkatkan kualitas ke-hidupan kita; ingin memenuhi potensi-potensi kita. Dengan ucapan Maslow sendiri, "What a man can be, he must be." Kebutuhan akan pemenuhan diri dilakukan melalui berbagai bentuk: (1) mengembangkan dan meng-gunakan potensipotensi kita dengan cara yang kreatif kons-truktif, misalnya dengan seni, musik, sains, atau hal-hal yang mendorong ungkapan diri yang kreatif; (2) memperkaya kualitas kehidupan dengan memperluas rentangan dan kualitas pengalaman serta pemuasan, misalnya dengan jalan darmawisata; (3) membentuk hubungan yang hangat dan berarti dengan orang-orang lain di sekitar kita; (4) berusaha "memanusia", menjadi persona yang kita dambakan."

Dalam hal ini, sebagai jurnalis di majalah anak yang pekerjaan utamanya adalah menulis, para jurnalis majalah Bobo berusaha memenuhi kebutuhan pemenuhan diri ini. Menulis adalah suatu kegiatan yang kreatif konstruktif. Dengan menulis mereka harus terus mengasah otak untuk menyajikan tulisan yang menarik dan sesuai dengan minat anak-anak yang terus mengikuti perkembangan zaman.।

\section{Pengalaman Jurnalis Majalah Bobo}

Jurnalistik adalah proses "aktivitas" atau "kegiatan" mencari, mengumpulkan, menyusun, mengolah/ menulis, mengedit, menyajikan, dan menyebarluaskan berita kepada khalayak melalui saluran media massa (Suryawati, 2011: 4). Yunus (2010: 16) mengatakan jurnalistik adalah pembuka informasi. Tugas utama jurnalistik adalah meng-hadirkan pengetahuan bagi masyarakat, mengikis ketidaktahuan yang terjadi. Pekerjaan sebagai jurnalis di media anakanak rupanya memiliki tantangan tersendiri dalam melakoninya. Jurnalis majalah anak dituntut untuk dapat menyajikan artikel-artikel sarat penge-tahuan dengan bahasa yang sederhana dan tidak menggurui pembacanya. Mereka harus selalu dapat menyejajarkan diri dengan anak-anak meski terpaut jarak usia yang jauh. Jurnalis majalah Bobo harus sering 
bergaul dengan anak-anak melalui kunjungan sekolah atau bermain bersama anak-anak di lingkungan sekitar mereka agar mereka terus dapat memahami dunia anak-anak masa kini. Selain bertanggung jawab untuk mengisi halaman di rubrik tetap majalah Bobo cetak, para jurnalis ini juga harus mengunggah tulisan mereka di laman bobo.id. Tulisan yang dimuat di situs daring majalah Bobo ini tidak sama dengan tulisan yang dimuat di majalah Bobo.

Sebagai jurnalis, mereka dituntut untuk memenuhi kebutuhan pembaca dan menyampaikan maksud sumber dan narasumber dengan tepat. Sebagai profesional, mereka harus mampu untuk memenuhi keinginan perusahaan. Di sinilah peran jurnalis sebagai mediator untuk memenuhi kebutuhan pembaca, perusahaan, dan narasumber.

Untuk menjelaskan pengalaman para jurnalis majalah Bobo, bagian ini akan dibagi kedalam bagaimana mereka memenuhi kebutuhan pembaca, memenuhi keinginan perusahaan, dan memenuhi keinginan narasumber.

Untuk memenuhi kebutuhan pembaca yang merupakan anak-anak, artinya para jurnalis majalah Bobo harus mampu memahami dunia anak, yang berarti hal pertama yang harus dilakukan adalah bertemu dengan anak-anak. Ana menceritakan, biasanya ada kunjungan dari sekolah ke redaksi majalah Bobo atau sebaliknya, anggota redaksi majalah Bobo berkunjung ke sekolah-sekolah. Dari situ, ia mengetahui apa yang sedang menarik minat anak-anak. Selain itu, ia juga mencari informasi di media sosial, misalnya dengan melihat topik yang sedang hangat di kalangan anak-anak. Selain itu, Ana juga sering berinteraksi dengan keponakannya yang masih kecil atau anak-anak di lingkungan sekitar tempat tinggalnya.

Ana juga bisa mendapatkan ide menarik dari mana saja. Misalnya, setiap hari Ana berjalan kaki menuju halte bus untuk ke kantor. Sambil berjalan, ia mendapati hal yang sama setiap kali melewati jalan yang sama, yaitu trotoar jalanan yang diperbaharui untuk Asian Games 2018. Hasil pengamatannya di jalan menuju kantor ini membuahkan dua artikel berjudul "Trotoar Baru di Jakarta untuk Menyambut Asian Games 2018" dan "Jalan Trotoar Khusus untuk Tunanetra" yang diunggah di laman bobo.id tanggal 5 Januari 2018.

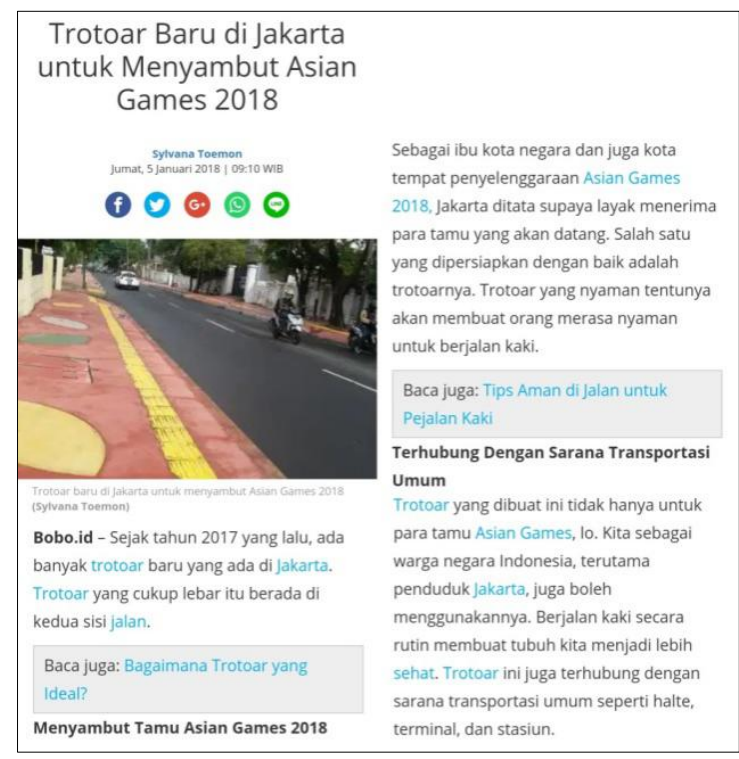

Gambar 1 Artikel Ana yang dimuat di laman bobo.id

http://jurnal.unpad.ac.id/kajian-jurnalisme 
Marisa mengatakan ia sering mencari ide dari media sosial seperti Instagram yang saat ini juga sedang digandrungi oleh anak-anak. Ia menceri-takan, pernah suatu kali ia menulis tentang membawa bekal ke sekolah dengan tema yang menarik. Ternyata, para pembacanya mengikuti apa yang dianjurkan Marisa melalui tulisannya. Mereka memotret bekal yang mereka bawa dan menandai akun Instagram majalah Bobo. Selain itu ia juga sering mengamati anak-anak di lingkungan tempat tinggalnya untuk mengetahui apa yang sedang mereka minati.

"Aku nulis coba kira-kira bikin bekal yang menarik, lucu-lucu. Ya udah aku bikin tulisan itu, ayo bawa bekal yang pakai tema. Misalnya temanya sunny gitu, ya udah bawa bekalnya yang warna-nya oranye, atau kuning. Jadi ada wortel, ada telur, atau ada jeruknya, kayak gitu. Dan itu diikutin sama anak-anak trus difoto di Instagram. Senang banget nggak sih? Aku sih senang banget ada feedback kaya gitu."

Veta kadang menemukan konten yang menarik untuk diangkat dari berbagai situs berita nasional. Misalnya, saat penelitian ini dilakukan Veta sedang menulis tentang siput laut. Menurutnya, jika media untuk segmentasi dewasa memuat informasi mengenai penemuan siput laut, maka majalah anak menuliskan dari sudut pandang lain, misalnya apa itu siput laut, bagaimana kehidupannya, dan sebagainya. Mereka lebih menekankan pada pengetahuan mengenai siput laut itu sendiri dibandingkan berita penemuannya.

Pengalaman lainnya, Veta pernah mengangkat topik tentang berita-berita hoaks yang sedang ramai di masyarakat. Permasalahan sosial yang aktual ini dapat terjadi dan memberikan dampak pada siapa saja, termasuk anak-anak. Majalah Bobo kemudian mengangkat fenomena ini dengan menyajikan artikel tips mem-bagikan dan/atau mengolah informasi. Melalui tulisannya, Veta berusaha me-nyampaikan pada anak-anak pembacanya untuk tidak mudah percaya pada suatu informasi dan harus mencari sumber lainnya. "Jadi ngikutin tren juga, tapi angle-nya beda," jelas Veta.

Yanti menjelaskan tantangan baginya dalam memahami dunia anak saat ini adalah bagaimana menemukan topik yang menarik bagi anak-anak. Sebab, saat ini minat baca anakanak mulai menurun dan digantikan oleh ketertarikan mereka terhadap gawai dan permainan digital. Yanti mengatakan, redaksi Bobo menyiasati hal ini dengan menyesuaikan tema dan membuat judul yang lebih menarik. Dalam mencari topik pun, menurut Yanti idealisme majalah Bobo sebagai teman bermain dan belajar bagi pembacanya tetap harus dikedepankan sehingga hasil tulisan tidak men-jerumuskan pembaca ke hal-hal negatif, atau sebaliknya, justru menjerumuskan majalah Bobo menjadi media promosi terselubung.

Materi untuk setiap artikel di majalah Bobo Yanti dapatkan dari berbagai sumber, mulai dari ensiklopedia, situs internet, wawancara dengan pakar, maupun liputan langsung ke lapangan. Liputan langsung ini biasanya dilakukan untuk rubrik "Potret Negeriku" yang membahas keindahan alam dan budaya Indonesia. Selain itu, Yanti mengatakan sumber liputan langsung bisa berasal dari undangan konferensi pers dan sebagainya. Hasil liputan konferensi pers ini pun dapat diangkat dari berbagai sudut pandang. 
Memenuhi keinginan perusahaan berarti para jurnalis majalah Bobo harus mampu mengikuti standar-standar yang ditetapkan oleh perusahaan, seperti jumlah tulisan yang harus disetor per hari, mencari topik yang menarik agar tetap menarik minat pembaca, hingga memenuhi kriteria penulisan yang tepat untuk anak-anak.

Veta mengatakan, mereka diminta untuk memuat 30 artikel per hari untuk bobo.id, yang terdiri dari artikel fiksi dan non-fiksi. Sementara untuk Bobo cetak, setiap Selasa seluruh tulisan harus sudah selesai diedit oleh editor untuk diteruskan ke bagian artistik dan percetakan, sehingga terdapat jeda sekitar tiga minggu dari tenggat waktu ke majalah Bobo edisi terbaru yang beredar di pasaran.

Sementara untuk nilai berita, Ana mengatakan nilai-nilai yang ada di Bobo tentunya sedikit berbeda dengan nilai berita yang ada di media segmentasi dewasa. Majalah Bobo tidak mengenal nilai berita seperti kontroversi, konflik, atau seksual. Nilai aktualitas pun diperhatikan tergantung aktualitas kalender, seperti hari-hari besar, atau peristiwa aktual yang dapat dikaitkan dengan pendidikan dan penanaman nilai yang positif bagi pembacanya. Nilainilai lainnya dapat dikaitkan dengan ketokohan, keluarbiasaan, atau kedekatan dengan pembacanya. "Misalnya, Raja Salman datang ke sini. Itu kita lihatlah, yang kita tulis itu, Raja Salman itu siapa, trus apa aja hal-hal positif yang sudah Raja Salman lakukan,” jelasnya.

Yanti menambahkan, hal-hal yang berkaitan dengan SARA (suku, agama, ras, dan antar golongan) sangat dihindari oleh majalah Bobo. Misalnya, Yanti men-contohkan saat itu ada liputan untuk rubrik "Potret Negeriku" di Papua.

“...liputan di Papua waktu itu ada yang tentang babinya gitu. Takutnya di sini jadi bahan SARA, gitu ya. Trus atau apalah gitu. Trus foto juga. Foto kalau misalnya orang Papuanya... ceweknya, atau cowoknya cuma pakai baju yang minim gitu, diedit juga."

Sebagai orang dewasa yang menulis untuk anak-anak, Ana tentunya berusaha memposisikan dirinya setara dengan anak-anak. Ia berusaha untuk tidak menggurui pembacanya melalui tulisan. Berkat hobinya menulis cerita anak sejak dulu, Ana tidak lagi mengalami kesulitan untuk menempatkan dirinya. Yanti mengatakan, ia berusaha untuk menasihati pembacanya tanpa menggurui dengan cara menghindari adanya simpulan. Ia membiarkan pembacanya menemukan makna sendiri dari apa yang mereka baca. Dengan demikian, Yanti bisa tetap memosisikan dirinya sebagai teman bagi anak-anak pembacanya. Yanti juga menceritakan, saat ini untuk melakukan wawancara ia tidak selalu menemui narasumber secara tatap muka. Biasanya, karena terjadi benturan kepentingan, yaitu kesibukan narasumber dan tenggat waktu yang harus dikejar oleh Yanti, ia pun sering memilih untuk melakukan wawancara melalui media sosial, telepon, atau surat elektronik (email). Walau demikian, Yanti mengakui ia lebih senang jika bisa melakukan wawancara langsung tatap muka. Wawancara melalui media sosial atau telepon ini tidak dipermasalahkan oleh perusahaan atau pemimpin redaksi selama data yang diberikan oleh narasumber benar adanya.

Adapun untuk kriteria teknis penulisan, Yanti mengatakan majalah Bobo menetapkan kriteria antara lain menggunakan bahasa yang sederhana, topik yang diangkat berhubungan 
160 | Kajian Jurnalisme

ISSN 2549-0559 (cetak) ISSN 2549-1946 (online)

Volume 01 Nomor 02 Tahun 2018

dengan dunia anak, dan pembahasan yang diangkat mudah dan ringkas. Bahasa yang digunakan adalah ragam bahasa tutur, seperti seorang anak yang berbicara dengan temannya. Meski demikian, standar penulisan di majalah Bobo tetap mengacu pada Ejaan yang Disempurnakan dan penggunaan kata yang baku sesuai dengan Kamus Besar Bahasa Indonesia. Penggunaan ragam bahasa tutur seperti "enggak"; atau penegasan dengan kata "nah" atau "lo"; masih diperbolehkan karena konteks bahasa tutur. Penggunaan honorifik untuk narsumber seperti "pak/bapak", "bu/ibu”, atau "kak/kakak" harus digunakan mengingat dalam artikel yang ditulis, mereka harus memosisikan diri sebagai anak usia sekolah dasar yang harus bersikap sopan pada orang yang lebih tua. Penggunaan bahasa asing sebisa mungkin dihindari dan diganti dengan padanan kata bahasa Indonesia. Ana mengatakan, mereka berusaha mengajak anak-anak untuk terbiasa membaca bacaan dengan bahasa Indonesia yang baik, tetapi tidak kaku dan masih dalam koridor yang sopan.

Untuk penulisan artikel, kalimat ditulis sependek mungkin, tidak lebih dari 15 kata dan menghindari kalimat bertingkat. Marisa pun menambahkan, artikel yang dibuat panjangnya sekitar $450 \mathrm{kata}$, karena akan diimbangi dengan ilustrasi. Penggunaan ilustrasi diperbanyak karena kecenderungan anak-anak yang lebih suka melihat gambar yang mengurangi kejenuhan mereka ketika membaca.

Marisa mengakui, selama perkuliahan dirinya tidak pernah diajarkan menulis untuk segmentasi anak-anak. Sebagaimana perkuliahan jurnalistik di berbagai kampus, ia diajarkan untuk meliput dan menulis berita untuk segmentasi dewasa. Pengetahuan tentang menulis untuk anak-anak ia dapatkan sambil belajar di majalah Bobo. Sejak magang di Bobo ia diajarkan untuk menulis sederhana dan jelas. Sama halnya dengan Veta yang satu kampus dengan Marisa. Ia baru belajar menulis untuk anak-anak setelah bekerja di majalah Bobo. Saat itu, ia diminta untuk membaca majalah Bobo edisi lama agar terbiasa dengan gaya bahasanya. Setelah itu ia menulis sendiri untuk kemudian dikoreksi oleh editor agar ia tahu dimana letak kesalahan dan kekurangannya.

Tantangan lain yang dihadapi oleh para jurnalis majalah Bobo adalah menyederhanakan bahasa, terutama bahasa ilmiah yang digunakan oleh narasumber mereka. Meski telah terbiasa menulis cerita anak dan memosisikan dirinya sebagai anak-anak pembaca, Ana masih mengakui kesulitan yang dialaminya selama bekerja di majalah Bobo tetap pada penggunaan bahasa, terutama pada penyederhanaan istilah. Bagi Ana, rubrik "Pengetahuan" adalah salah satu rubrik yang menjadi tantangan baginya karena ia harus memutar otak untuk menyeder-hanakan bahasa ilmiah menjadi ragam bahasa tutur untuk anak-anak. Begitu pula dengan penggunaan kata asing yang sudah umum digunakan, tetapi sekarang harus ditulis sesuai dengan kata serapan dalam bahasa Indonesia.

Seperti Ana, kesulitan yang dirasakan Veta selama bekerja di Bobo adalah pada masalah dalam penulisan dan penyederhanaan istilah. Namun, ia mengakali hal tersebut dengan mem-bayangkan dirinya kembali menjadi anak-anak. Ia juga membaca tulisannya berkali-kali untuk memastikan artikel yang ditulisnya mudah dimengerti hanya dalam satu kali baca. Veta mengaku ia merasa canggung ketika pertama kali menulis di majalah Bobo karena perbedaan yang ia rasakan dari menulis untuk segmentasi dewasa ke segmentasi anak- 
anak. Semasa awal bekerja di majalah Bobo, Veta di-bimbing oleh senior-seniornya agar ia terbiasa dengan gaya penulisan untuk anak-anak sebelum akhirnya dilepas untuk menulis sendiri.

Sumber-sumber artikel pengetahuan yang digunakan Veta antara lain ensiklopedia, situs-situs pengetahuan, atau situs resmi lembaga seperti NASA dan semacamnya. Selain itu, Veta juga sering melakukan wawancara ke pakar, sesuai dengan topik yang ditulis. Saat melakukan wawancara, Veta biasanya meminta bantuan mereka untuk menyederhanakan istilah-istilah teknis, sehingga apa yang ia tulis nanti sesuai dengan apa yang dimaksud oleh si narasumber.

“... itu biasanya $u$ dah diomongin dari pertama. Misalnya ada bahasa apa nanti ditanya ke dokternya, 'Dok, itu tuh gimana ya kalau misalnya gampangnya gimana bahasanya?' atau kalau nggak begitu dokternya ngomong, kita coba merangkum dengan bahasa kita, bener apa nggak, melenceng apa nggak dari penjelasan dokternya, jadi konfirmasi langsung ke dokternya."

Yanti juga mengakui, selama 17 tahun ia bekerja di majalah Bobo, menyederhanakan istilah teknis masih menjadi tantangan baginya. Apalagi, menurut Yanti, terkadang narasumber juga sering merasa kebingungan untuk membantunya menyederhanakan istilah. Yanti pun mengakali hal ini dengan terus menerus melakukan pemeriksaan kembali (crosscheck) hingga ia berhasil me-nyampaikan apa yang dimaksud oleh pakar dengan bahasa yang sederhana dan cocok untuk anak-anak.

"Waktu itu kita pernah bikin penyakit yang dari susu itu tuh, enterobacter zaka zaki apa, itu juga kan aku wawancara dokter, dokternya juga, 'silahkan Anda itu tugas Anda menerjemahkan data ini kepada anak-anak itu harusnya seperti apa.' Itu susah kan ya. Nanti kita coba tulis, disederhanain, kasih lihat ke dia. Ternyata 'oh ini salah, begitu kurang tepat.' Gitu terus aja crosscheck bolak-balik."

Saat menulis, Yanti selalu membayangkan dirinya berada di posisi anak-anak, sehingga ia bisa melihat permasalahan yang mereka hadapi atau sesuatu yang menarik minat mereka. Namun, Yanti mengakui ketika pertama kali bekerja ia merasa kesulitan untuk menempatkan dirinya setara dengan anak-anak. Seiring berjalannya waktu, Yanti mulai terbiasa dengan gaya majalah Bobo dan kesulitan yang dirasakan tidak lagi sebesar ketika ia pertama kali bekerja.

Marisa juga mengakui kesulitan terbesar yang ia rasakan selama bekerja di majalah Bobo adalah masalah penulisan. Majalah Bobo menuntutnya untuk tetap menggunaan ejaan bahasa Indonesia yang baku yang ditulis dengan gaya bahasa tutur. Begitu pula dengan pemilihan kata yang harus diberi perhatian khusus.

Suryawati (2011: 4) mengatakan jurnalistik adalah proses "aktivitas" atau "kegiatan" mencari, mengumpulkan, menyusun, mengolah/menulis, mengedit, menyajikan, dan menyebarluaskan berita kepada khalayak melalui saluran media massa. Dalam konteks jurnalis majalah Bobo ini, proses "aktivitas" mencari dan mengumpulkan berita tidak selalu berarti mereka harus turun ke lapangan, melakukan wawancara cegatan atau doorstop, maupun meliput suatu peristiwa dan mewartakannya secara real-time. Kegiatan mencari dan 
162 | Kajian Jurnalisme

ISSN 2549-0559 (cetak) ISSN 2549-1946 (online)

Volume 01 Nomor 02 Tahun 2018

mengumpulkan berita biasa dilakukan dengan meng-andalkan sumber internet, buku, koran harian, atau wawancara dengan ahli, yang kemudian disusun dan diolah sedemikian rupa agar sesuai untuk target khalayak pembacanya. Maka, kegiatan para jurnalis majalah Bobo ini dapat disebut sebagai kegiatan jurnalistik.

Zaenuddin HM (2011:9-10) menuliskan fungsi media massa antara lain untuk menghimpun dan menyebarkan informasi bagi khalayak masyarakat; memberikan pendidikan bagi khalayak masyarakat; dan sebagai media hiburan bagi khalayak masyarakat. Hal-hal tersebut sejalan dengan peran jurnalis majalah Bobo yang berusaha menyajikan informasi, pengetahuan, dan hiburan bagi khalayak pembacanya. Dalam pe-kerjaannya, jurnalis majalah Bobo banyak berinteraksi dengan orang lain, yaitu anak-anak, narasumber, dan kolega mereka di kantor. Para informan ini sebelumnya tidak pernah mendapat pelajaran formal tentang menulis untuk anak-anak. Saat pertama kali bekerja di Bobo, mereka selalu diminta untuk membaca artikel-artikel dari Bobo edisi lama, serta meminta senior mereka untuk membantu meng-oreksi tulisan mereka agar sesuai dengan kriteria yang ditetapkan oleh majalah Bobo. Interaksi para informan dengan pembaca, narasumber, dan kolega mereka itu dapat dijelaskan dengan Teori Interaksi Simbolik. Teori yang digagas oleh filsuf George Herbert Mead ini menekankan pada komunikasi dalam membentuk dan mengelola hubungan interpersonal. Masyarakat, diri, dan pikiran merupakan tiga konsep penting dalam teori ini. Mengenai konsep “masyarakat”, Littlejohn (2014: 233) mengatakan,

"Kerja sama manusia meng-haruskan kita untuk memahami maksud orang lain yang juga mengharuskan kita untuk me-ngetahui apa yang akan kita lakukan selanjutnya. Jadi, kerja sama terdiri dari "membaca" tindakan dan maksud orang lain serta menanggapinya dengan cara yang tepat."

Secara luas, "masyarakat" bagi para jurnalis majalah Bobo mencakup narasumber serta khalayak pembacanya. Misalnya, ketika harus mewawancarai dokter, mereka harus mampu mener-jemahkan bahasa ilmiah atau bahasa kesehatan menjadi bahasa yang lebih sederhana, sehingga sesuai dengan maksud si narasumber (dokter) dan tetap dapat dipahami dengan mudah oleh pembacanya (anak-anak). Begitu pula ketika mereka harus menggunakan kata serapan yang meski terdengar tidak familiar, tetapi harus tetap digunakan karena standar majalah Bobo yang harus sesuai dengan Kamus Besar Bahasa Indonesia.

Sebagai orang dewasa yang menyajikan informasi untuk anak-anak, para informan harus membiasakan dirinya untuk berpikir seperti anak-anak. Littlejohn (2014: 235) menjelaskan, berpikir merupakan konsep ketiga Mead, yang disebut pikiran. Ia kemudian menuliskan,

"Pikiran bukanlah sebuah benda, tetapi merupakan sebuah proses. Hal ini tidak lebih dari sekadar berinteraksi dengan diri Anda sendiri. Kemampuan ini, yang berkembang sejalan dengan diri, sangat penting bagi kehidupan manusia karena merupakan bagian dari setiap tindakan manusia. Berpikir melibatkan keraguan (menunda tindakan yang jelas) ketika Anda menafsirkan situasi. Di sini, Anda berpikir melalui situasi dan merencanakan tindakan selanjutnya. Anda membayangkan beragam hasil dan memilih serta menguji alternatif-alternatif yang mungkin ada." 
Kemampuan para informan untuk menempatkan dirinya pada posisi anak-anak pembacanya adalah hasil dari proses berpikir. Para informan membayangkan bagaimana mereka dulu ketika kanak-kanak, bagaimana problematika yang dihadapi anak masa kini, dan bagaimana pikiran mereka ketika membaca sebuah tulisan yang panjang dengan bahasa yang rumit. Hasilnya, para informan pun mampu untuk mencari topik yang dapat menarik minat pembacanya dan menggunakan bahasa jurnalistik yang cocok untuk anak-anak. Sumadiria (2006: 82), mengatakan, bacaan bagi anak-anak menggunakan paragraf dan kalimat-kalimat yang pendek-pendek, serta kata-kata yang sesuai dengan perkembangan jiwa mereka. Hasil dari interaksi para informan dengan masyarakat dan pikirannya itu adalah artikel yang disajikan menjadi seperti seorang teman bercerita pada temannya yang lain, bukan sebagai orang dewasa yang menggurui.

Upaya para informan untuk dapat memenuhi keinginan pembaca, perusa-haan, dan narasumber tersebut dapat dikatakan sebagai tindakan yang dipengaruhi oleh motif untuk (inorder-to motive) dan motif sebab (because motive) seperti yang dikatakan Schutz. Interaksi para informan dengan anak-anak di sekitarnya, misalnya dengan sepupu atau keponakan mereka atau anak-anak yang berkunjung dari sekolah, awalnya bisa saja terjadi karena adanya motif pertama (motif untuk), yaitu "bermain dengan keponakan/ sepupu" atau "menyambut anak-anak yang berkunjung". Setelah itu, muncullah motif kedua (motif sebab) ketika mereka telah berinteraksi dan mengetahui apa saja hal-hal yang menarik minat anakanak. Motif kedua ini kemudian mendorong informan untuk melakukan sebuah tindakan, yaitu menyajikan artikel yang sesuai dengan kebutuhan anak-anak pembacanya.

Yanti, misalnya, menceritakan tantangan baginya saat ini adalah menemukan topik yang menarik bagi anak-anak. Ia pun berusaha untuk mencari tahu tren terkini di kalangan anak-anak dan memutar otak untuk menyajikan judul yang lebih menarik. Misalnya, ketika penelitian ini dilakukan, redaksi majalah Bobo sedang mengerjakan artikel untuk tema $M y$ Little Pony. Menurut Yanti, sebelum tema ini akhirnya diangkat, mereka telah memiliki tema lain. Namun, melihat saat itu mendekati penayangan film My Little Pony dan banyaknya permintaan untuk mengangkat tema tersebut dari surat yang dikirimkan pembaca, maka tema yang tadinya telah ditentukan pun diganti. Tindakan mengganti tema itu dipengaruhi oleh motif pertama, yaitu banyaknya permintaan dari pembaca, dan motif kedua yang merujuk pada masa lalu, dimana topik yang banyak diminati akan menarik minat pembaca.

Pengaruh motif pertama (in-order-to motive) juga terdapat dalam penentuan nilai berita dan penggunaan filter informasi yang disajikan. Ana menekankan, artikel dan cerita yang dimuat di majalah Bobo harus dapat dikaitkan dengan pendidikan dan penanaman nilai yang positif bagi pembacanya. Hal-hal yang bersinggungan dengan SARA pun dihindari agar tidak memberikan dampak negatif, baik bagi pembaca maupun bagi masyarakat secara umum. Tindakan untuk menyajikan artikel yang sarat nilai positif ini dipengaruhi oleh motif pertama yang merujuk pada masa yang akan datang, yaitu agar pembaca mendapatkan manfaat positif dari artikel yang disajikan oleh para jurnalis majalah Bobo. 
164 | Kajian Jurnalisme

ISSN 2549-0559 (cetak) ISSN 2549-1946 (online)

Volume 01 Nomor 02 Tahun 2018

\section{Konsep Diri Jurnalis Majalah Bobo}

Profesi jurnalis biasanya identik dengan sesuatu yang heroik. Yunus (2010: 38) mengatakan profesi wartawan merupakan profesi yang disegani oleh publik. Sebab, wartawan dianggap kritis dan tajam dalam bertanya, mampu mengungkap informasi secara rinci, piawai dalam meliput berita, dan mampu mempengaruhi orang lain melalui tulisannya. Jurnalis dianggap sebagai seseorang yang selalu menguak kebenaran, menembus batas-batas birokrasi, mengkritik pemerintah sehingga dapat mengancam keselamatan diri jurnalis tersebut. Sementara, profesi jurnalis di media anak-anak tidak mencakup ranah berbahaya seperti itu. Namun, para informan rupanya juga memaknai profesi mereka sebagai sesuatu yang heroik, tetapi dengan cara yang berbeda. Para jurnalis majalah Bobo memaknai dirinya sebagai pribadi yang mendidik dan membantu membangun generasi penerus bangsa.

Fitts (dalam Agustiani, 2006) membagi konsep diri menjadi dua dimensi pokok, yaitu dimensi internal yang merupakan penilaian individu terhadap dirinya sendiri; dan dimensi eksternal yang berkaitan dengan hubungan dan aktivitas sosial, nilai yang dianut, serta hal-hal lain di luar dirinya. Bagian ini akan dijabarkan berdasarkan dua dimensi pokok yang dikemukakan Fitts tersebut, utamanya berkaitan dengan konsep diri informan sebagai jurnalis di majalah Bobo.

Ana memilih untuk mendeskripsikan profesinya sebagai penulis, bukan wartawan atau jurnalis. Sebab, menurutnya predikat jurnalis melekat pada orang-orang yang bekerja di koran harian atau televisi berita dan mewartakan fakta aktual. Sementara di majalah Bobo, ia tidak selalu menuliskan hal-hal aktual, melainkan juga pengetahuan umum yang tak lekang oleh waktu.

"Kalau yang kayak wartawan, yang bayangan aku ya, yang kayak di koran, apa tv gitu, yang ada kejadian sesuatu, kita mewartakan dan sebenar-benarnya. Dan kalau di sini tuh enggak. Kita emang nggak semua hal kita wartakan sebagai fakta. Yang kita wartakan emang ada pengetahuan, yang kita udah tahu ada gunanya gitu." (Ana, Wawancara, 19 September 2017)

Ana menganggap ia berperan dalam membangun peradaban melalui tulisantulisannya. Ana berupaya untuk menyajikan bacaaan menarik bagi anak-anak sehingga minat baca mereka semakin meningkat. Bagi Ana majalah Bobo menyajikan pengetahuan dan hiburan bagi anak-anak dengan ringan dan harga yang bersahabat. Sebagai penulis atau jurnalis di majalah Bobo, Ana memandang dirinya sebagai teman bermain dan belajar bagi pembacanya. Ia selalu memosisikan diri sebagai teman yang lebih dulu tahu dibandingkan teman lainnya, kemudian menyampaikan pengetahuan itu kepada mereka. Dengan demikian, Ana dapat menghindari gaya bahasa yang menggurui.

Veta menganggap heroiknya jurnalis media anak terletak pada peran mereka yang membantu untuk mencerahkan dan membimbing anak-anak pembacanya. Jurnalis anak berperan untuk membimbing anak-anak dan menjaga pemikiran mereka agar tidak mengarah pada hal-hal negatif. Apalagi dengan perkembangan teknologi seperti saat ini, anak-anak bisa mengakses informasi apa saja di internet. Untuk itu, jurnalis media anak lah yang berperan untuk mencari topik menarik agar anak-anak berminat untuk membaca pengetahuan yang baik dan berguna bagi mereka. Veta menambahkan, peran jurnalis majalah anak seperti 
majalah Bobo adalah memenuhi berbagai kebutuhan mereka. Para jurnalis majalah Bobo berusaha memenuhi kebutuhan anak-anak akan pengetahuan yang tidak mereka dapatkan dari pembelajaran di sekolah. Mereka juga berusaha membantu anak-anak untuk mengasah kreativitas dengan menyediakan cerita pendek, dongeng, cerita bergambar, atau kegiatan prakarya. Selama bekerja di majalah Bobo, manfaat yang Veta dapatkan adalah pengetahuannya yang bertambah. Sebab, menurutnya, sebelum ia menyampaikan pengetahuan dalam bentuk artikel, ia harus banyak membaca berbagai sumber untuk pengetahuan tersebut.

Bagi Marisa, sisi heroik dari pekerjaan yang ia lakoni saat ini adalah bagaimana ia dapat menginspirasi dan membagikan hal-hal bermanfaat bagi pembacanya. Dengan memberikan asupan nilai-nilai positif pada anak-anak, ia merasa berperan dalam membentuk kepribadian mereka. Apalagi, berdasarkan pengalamannya melakukan tugas peliputan mendalam selama kuliah, Marisa merasa semangatnya (passion) bukan di ranah yang bertugas untuk menumpas atau membongkar suatu kejahatan. Ia lebih memilih untuk melakukan sesuatu yang ia senangi dan memberikan dampak positif bagi pembacanya. Marisa pun menganggap dirinya adalah jurnalis anak-anak. Sebab, menurutnya apa yang ia lakoni sekarang berbeda dengan anggapan umum tentang jurnalis yang identik dengan orangorang yang melakukan peliputan lapangan terus menerus, berjaga di lokasi tertentu seperti kantor polisi atau gedung DPR, atau yang berpakaian lusuh dan selalu pergi mencari berita dengan mengenakan celana jeans.

Sewaktu kecil, Yanti bercita-cita menjadi guru. Saat ini, ia merasa cita-citanya itu telah tercapai meski dalam bentuk berbeda, yakni dengan menjadi jurnalis di majalah anak. Maka, Yanti pun melihat dirinya sebagai guru yang tidak menggurui. "Kalau guru kan ngomong langsung di depan kelas, kalau ini ngomongnya lewat tulisan. Sebenernya sama aja yang menyampaikan ilmu dengan cara yang berbeda, gitu." jelasnya. Bagi Yanti, dengan menjadi jurnalis di majalah anak ia tetap dapat menyampaikan ilmu yang bermanfaat bagi pembacanya dengan cara yang menyenangkan, sehingga anak-anak pembacanya tidak merasa mereka sedang diberi materi pelajaran seperti yang diajarkan di sekolah. Tidak hanya itu, bagi Yanti, jurnalis majalah anak juga bertanggung jawab dalam menyampaikan kebenaran yang harus diperiksa berkali-kali.

Konsep diri seseorang dipengaruhi oleh orang lain (significant others) dan kelompok rujukan (reference group). Gabriel Marcel, filosof eksistensialis, yang mencoba menjawab misteri keberadaan, The Mystery of Being, menuliskan peranan orang lain dalam memahami diri kita, "the fact that we can understand ourselves by starting from the other, or from others, and only by starting from them." Kita mengenal diri kita dengan mengenal orang lain lebih dulu (Rakhmat, 2009: 99).

Littlejohn (2014: 122) dalam pengantarnya mengenai Teori Interaksi Simbolik mengatakan, diri sendiri merupakan sebuah objek sosial yang penting, dijelaskan dan dipahami dengan cara yang selalu berkembang dalam interaksi dengan orientational others.

"Konsep diri Anda tidak lebih dari rencana tindakan Anda terhadap diri sendiri, identitas, minat, keengganan, cita-cita, ideologi, dan penilaian diri Anda." 
166 | Kajian Jurnalisme

ISSN 2549-0559 (cetak) ISSN 2549-1946 (online)

Volume 01 Nomor 02 Tahun 2018

Mead (dalam Littlejohn, 2014: 233) mengatakan dalam masyarakat atau kehidupan kelompok terdiri atas perilaku-perilaku kooperatif anggota-anggotanya. Kerja sama manusia mengharuskan kita untuk memahami maksud orang lain yang juga mengharuskan kita untuk mengetahui apa yang akan kita lakukan selanjutnya. Jadi, kerja sama terdiri dari "membaca" tindakan dan maksud orang lain serta menanggapinya dengan cara yang tepat.

Ana merupakan pekerja media yang sehari-hari berkutat di bidang jurnalistik. Jurnalistik dapat didefinisikan sebagai proses "aktivitas" atau "kegiatan" mencari, mengumpulkan, menyusun, mengolah/menulis, mengedit, menyajikan, dan menyebarluaskan berita kepada khalayak melalui saluran media massa (Suryawati, 2011: 4). Meski demikian, Ana tidak mendefinisikan dirinya sebagai wartawan. Pemaknaan Ana terhadap kata "wartawan" sebagai "yang kayak di koran, apa tv gitu, yang ada kejadian sesuatu, kita mewartakan dan sebenar-benarnya" muncul dari hasil interaksi atau observasinya dengan wartawan koran harian atau televisi berita. Dari sana, Ana kemudian melihat ke dalam dirinya sendiri. Ia membandingkan ranah jurnalistik yang ia kerjakan dengan ranah jurnalistik yang "wartawan" kerjakan. Fitts (dalam Agustiani, 2006) mengatakan salah satu bagian dari dimensi internal konsep diri adalah Diri Identitas (identity self) yang mengacu pada pertanyaan "siapa saya?" Pertanyaan ini berhubungan dengan pengetahuan individu mengenai dirinya dan semakin kompleks seiring dengan interaksinya dengan lingkungan. Dari sini terlihat bahwa Ana melabeli diri dan profesinya sebagai penulis yang tetap menyajikan fakta berupa pengetahuan.

Konsep diri Ana sebagai teman bermain dan belajar muncul karena ia terbiasa memosisikan diri sebagai teman yang lebih dulu tahu dibandingkan teman lainnya. Hal ini sejalan dengan peng-alamannya bergaul dengan anak-anak untuk memahami dunia mereka. Konsep diri internal ini dikemukakan oleh Fitts sebagai Diri Perilaku (behavioral self). Diri perilaku merupakan persepsi individu tentang tingkah lakunya yang berisi segala kesadaran mengenai "apa yang dilakukan oleh diri." Diri perilaku ini muncul berdasarkan umpan balik yang bersifat eksternal maupun internal terhadap perilaku yang ditampilkan individu. Umpan balik yang positif dari orang lain otomatis akan membuat seorang individu mempertahankan perilakunya tersebut. Umpan balik yang positif didapat Ana dari editornya dan pembaca yang menyukai tulisannya. Konsep jurnalis yang heroik pun didapat Ana dari pikirannya tentang peradaban yang dibangun melalui tulisan. Ana merasa dirinya membantu upaya peningkatan minat baca anak-anak dengan bergabung di majalah Bobo. Konsep diri internal ini pun berkaitan dengan konsep diri eksternal yang dikemukakan Fitts, yaitu bentuk diri sosial yang berupakan persepsi dan penilaian individu mengenai interaksi dirinya dengan orang lain maupun dengan lingkungan sekitarnya yang lebih luas. Kedua dimensi internal dan eksternal inilah yang melahirkan konsep diri Ana sebagai penulis sekaligus teman bermain dan belajar.

Konsep diri seseorang juga dipengaruhi oleh orang lain (significant others) dan kelompok rujukan (reference group). Mengenai tanggapan orang lain mengenai pekerjaan yang ia lakoni sekarang, Marisa mengatakan keluarganya sejauh ini mendukung dan tidak berkomentar banyak mengenai pilihan kariernya. Sementara dari orang lain seperti teman atau kolega yang baru dikenalnya, menurut Marisa biasanya mereka selalu mengajukan 
pertanyaan seperti “Bobo? Masih ada?" Ada nada satir dalam pertanyaan itu dan Marisa menirukannya dengan nada jenuh karena ia begitu sering menerima pertanyaan seperti itu.

Dalam hal ini, ketika Marisa bertemu masyarakat, mereka mengajukan pertanyaanpertanyaan yang sama tentang eksistensi majalah Bobo tempatnya bekerja. Meski jenuh dengan pertanyaan-pertanyaan senada, Marisa masih dapat menanggapi pertanyaan basa-basi tersebut dengan kepala dingin. Jika mendapat pertanyaan seperti itu, Marisa hanya menanggapi dengan, "Masih ada dooong. Kita udah mau 44 tahun loh. Ya walaupun istilahnya udah nggak segaul dulu ya, karena emang dunia digital itu keluar," katanya sambil tertawa.

Dilihat dari dua dimensi yang dijabarkan Fitts, bisa dikatakan Marisa melihat dirinya sebagai sosok yang menginspirasi karena ia merasa tulisan-tulisan yang dibuatnya dapat memberikan hal positif bagi pembacanya. Marisa kemudian memikirkan dirinya sebagai seseorang yang dapat menginspirasi dan membagikan hal-hal bermanfaat bagi pembacanya. Pemikiran ini muncul karena Marisa berinteraksi dengan anak-anak pembacanya melalui tulisannya yang mengandung pengetahuan dan nilai-nilai positif. Hal ini berarti berkaitan dengan diri perilaku Marisa. Diri Identitasnya sebagai jurnalis untuk anak-anak pun muncul dari konsep diri eksternal, yaitu Diri Fisik dimana Marisa merasa penampilan fisiknya, yang dinilai dari cara berpakaian, berbeda dengan jurnalis koran harian atau televisi berita. Dari interaksi Marisa dengan masyarakat dan hasil refleksinya terhadap dirinya sendiri, maka didapatlah konsep diri Marisa sebagai sosok yang mendidik dan bermanfaat.

Konsep diri sebagai jurnalis yang heroik didapat Veta karena ia merasa membantu mencerahkan dan membimbing anak-anak pembacanya. Konsep diri ini dipengaruhi oleh inorder-to motive atau tujuan Veta yang ingin mampu menyajikan artikel yang menarik minat baca anak-anak daipada mereka membaca hal-hal yang tidak bermanfaat. Bagian yang disebut Fitts sebagai Diri Perilaku ini membuat Veta merasa bahwa dirinya adalah filter atau penyaring informasi bagi pembacanya. Hal ini kemudian memunculkan identitas Veta sebagai jurnalis. Dilihat dari dimensi eksternal, diri sosial Veta merujuk pada interaksinya dengan anak-anak sebagai pembacanya. Diri sosial ini mendorong Veta untuk bisa memenuhi kebutuhan mereka. Selain itu, bagi Veta kegiatan jurnalistik memberikan manfaat untuk dirinya karena ia merasa pengetahuannya bertambah berkat artikel-artikel yang ditulisnya.

Konsep diri Yanti sebagai sosok yang menyampaikan ilmu bermanfaat muncul karena adanya pengaruh because-motive yang merujuk pada masa lalunya yang bercita-cita menjadi guru. Morissan (2009: 76) mengatakan, konsep diri Anda tidak lebih dari rencana tindakan Anda terhadap diri Anda, identitas Anda, ketertarikan, kebencian, tujuan, ideologi, serta evaluasi diri Anda. Konsep diri ini hadir dari tujuan Yanti yang ingin menyampaikan ilmu yang bermanfaat bagi pembacanya, yang juga merujuk pada dimensi Diri Perilaku. Identitas Yanti sebagai jurnalis pun memunculkan konsep dirinya yang bertanggung jawab menyampaikan kebenaran, karena kewajiban pertama jurnalistik adalah pada kebenaran. Hal ini tentunya berkaitan dengan Diri Sosial, dimana Yanti telah berinteraksi dengan kolega dan pembacanya yang terus menantang dirinya untuk menyajikan informasi yang sarat manfaat. 
168 | Kajian Jurnalisme

ISSN 2549-0559 (cetak) ISSN 2549-1946 (online)

Volume 01 Nomor 02 Tahun 2018

\section{Simpulan}

Motif jurnalis bergabung dengan majalah Bobo dipengaruhi oleh motif sebab (becausemotive) yang memengaruhi tindakan mereka dalam memilih profesinya. Motif ini terdiri atas sesuai dengan latar belakang pendidikan, menyukai dunia anak-anak, dan membutuhkan pekerjaan. Selain itu, motif para jurnalis dalam memilih pekerjaannya dipengaruhi oleh motif sosiogenis, yaitu motif kompetensi dan kebutuhan pemenuhan diri.

Pengalaman jurnalis majalah Bobo lahir dari proses berpikir serta motif untuk (inorder-to motive) dan motif sebab (because motive) saat mereka bergaul dengan anak-anak. Pengalaman jurnalis majalah Bobo terdiri atas memenuhi kebutuhan pembaca, yaitu dengan ber-usaha menyajikan artikel yang aktual sesuai minat anak dan mendidik; memenuhi keinginan perusahaan, yaitu dengan mengikuti standar-standar yang ditetapkan oleh perusahaan, seperti jumlah tulisan yang harus disetor per hari, mencari topik yang menarik agar tetap menarik minat pembaca, hingga memenuhi kriteria penulisan yang tepat untuk anak-anak. Kriteria penulisan yang tepat untuk anak adalah menghindari topik yang bersinggungan dengan SARA, menempatkan diri sebagai anak-anak, dan menghindari simpulan agar tidak menggurui pembacanya. Sementara kriteria teknis penulisan yaitu menggunakan gaya bahasa tutur, tetap mengacu kepada pedoman ejaan yang disempurnakan, kalimat ditulis pendek, dan menghindari kalimat bertingkat; dan memenuhi keinginan narasumber, yaitu dengan berusaha menuliskan kembali penjelasan narasumber yang bersifat ilmiah menjadi gaya bahasa tutur yang lebih sederhana tanpa menggeser maknanya.

Konsep diri jurnalis majalah Bobo adalah sebagai teman bermain dan belajar, sebagai pribadi yang membantu membangun generasi bangsa, sebagai sosok yang membantu mencerahkan dan membimbing anak-anak, memberikan pengetahuan yang tidak didapatkan dari pelajaran sekolah, sebagai sosok yang menginspirasi dan membagikan hal-hal bermanfaat bagi pembaca, sebagai sosok yang menyampaikan ilmu bermanfaat, dan bertanggung jawab menyampaikan kebenaran.

Maka, dapat disimpulkan bahwa makna jurnalistik bagi jurnalis majalah anak adalah kegiatan yang positif, mendidik, dan dapat memberikan manfaat bagi pembacanya.

\section{Saran}

Saran untuk jurnalis majalah Bobo: Selama ini majalah Bobo lebih sering mengangkat sisi pengetahuan dari suatu tragedi. Ada baiknya jika para jurnalis menantang diri untuk menuliskan sisi humanis dari suatu tragedi agar anak-anak dapat memahami emosi kesedihan dan menumbuhkan empati mereka.

Saran untuk penelitian selanjutnya: Perlu ada penelitian selanjutnya yang membahas tentang kebutuhan anak-anak akan karya jurnalistik berkualitas, dan kriteria karya jurnalistik untuk anak yang menyesuaikan dengan perkembangan zaman, baik dalam format cetak (majalah), daring (online), televisi, maupun radio. 
Kajian Jurnalisme

ISSN 2549-0559 (cetak) ISSN 2549-1946 (online)

Volume 01 Nomor 02 Tahun 2018

\section{Daftar Pustaka}

Agustiani (2006). Psikologi Perkembangan: Pendekatan Ekologi Kaitannya dengan Konsep Diri dan Penyesuaian Diri Para Remaja. Bandung: PT Refika Aditama.

Ahmadi, Rulam (2014). Metodologi Penelitian Kualitatif. Yogyakarta: Ar-Ruzz Media.

Ermanto (2005). Menjadi Wartawan Handal dan Profesional: Panduan Praktis dan Teoritis. Yogyakarta: Cinta Pena.

Idrus, Muhammad (2009). Metode Penelitian Ilmu Sosial: Pendekatan Kualitatif dan Kuantitatif, Edisi Kedua. Jakarta: Erlangga.

Kuswarno, Engkus (2009). Metodologi Penelitian Komunikasi Fenomenologi: Konsepsi, Pedoman, dan Contoh Penelitiannya. Bandung: Widya Padjadjaran.

Littlejohn, Stephen W., dan Karen A. Foss (2009). Teori Komunikasi Edisi 9. Jakarta: Salemba Humanika.

Moleong, Lexy J (2012). Metodologi Penelitian Kualitatif. Bandung: Remaja Rosdakarya.

Morissan (2013). Teori Komunikasi: Individu Hingga Massa. Jakarta: Kencana.

Mulyana, Deddy (2013). Metodologi Penelitian Kualitatif: Paradigma Baru Ilmu Komunikasi dan Ilmu Sosial Lainnya. Bandung: Remaja Rosdakarya.

Mustaqim Amna (2016). Skripsi: Perjalanan Bobo dari Tahun 1973 hingga 2015. Jatinangor: Fakultas Ilmu Komunikasi Universitas Padjadjaran.

Pustaka Setia (2012). Pedoman Umum Ejaan Bahasa Indonesia yang Disempurnakan dan Pedoman Umum Pembentukan Istilah. Bandung: Pustaka Setia.

Rakhmat, Jalaluddin (2011). Psikologi Komunikasi. Bandung: Remaja Rosdakarya.

Sumadiria, AS Haris (2006). Bahasa Jurnalistik: Panduan Praktis Penulis dan Jurnalis. Bandung: Simbiosa Rekatama Media.

Suryawati, Indah (2011). Jurnalistik: Suatu Pengantar. Bogor: Ghalia Indonesia.

Yunus, Syarifudin (2010). Jurnalistik Terapan. Bogor: Ghalia Indonesia.

http://jurnal.unpad.ac.id/kajian-jurnalisme 